Hydrol. Earth Syst. Sci. Discuss., https://doi.org/10.5194/hess-2018-498

\title{
Values in water management
}

\author{
Erik Mostert \\ Department Water Management, Delft University of Technology, Stevinweg 1, 2628 CN Delft, the Netherlands \\ Correspondence to: Erik Mostert (e.mostert@tudelft.nl)
}

5 Abstract. Values, defined as principles or standards of behaviour, are crucial for understanding how individuals, groups, organisations and whole societies interact with their water systems. Values can be used to judge and justify actions (ideal values) and they can be enacted in practice and embodied in water laws and water infrastructure (actual values). Moreover, they can be individual or social. Depending on the type of value, different measurement methods can be used. For research into the co-evolution of human and water systems, discourse analysis of cultural texts such as newspaper articles is a good method since such texts are often available for longer periods. For comparative research, data from the World Values Survey or the European Social Survey may be used. To achieve progress, future socio-hydrological research should take as its starting point the main social groups and organisations in the area of concern and study 1) how these have evolved, 2) how their interactions with each other and with their physical environment have evolved, and 3) how they influence and are influenced by the prevalent social values and management institutions.

\section{Introduction}

Values play an important role in water management. Values can be described as "principles or standards of behaviour; one's judgement of what is important in life" (Stevenson, 2010). Without sufficient knowledge of the prevalent values, it will be very hard to understand human behaviour.

Recently, Roobavannan et al. (2018) reviewed the role of values in socio-hydrological models. To improve the generalisability and predictive power of these models, they proposed the use of Values-Beliefs-Norms (VBN) theory (Stern et al., 1999; Stern, 2002). VBN theory has been developed to explain pro-environmental behaviour, such as environmental activism and support of environmental policies. It explains this behaviour by pro-environmental personal norms, which in turn are explained by 1) relatively stable personal values, and 2) personal beliefs that the realisation of these values is threatened and that the individual can help to alleviate the threat. VBN theory has been used to explain for instance climate change mitigation and adaptation measures by farmers (Sanderson and Curtis, 2016) and support of farmers and non-farmers for water policies (Sanderson et al., 2017). It is, however, not a complete theory of values. What is missing is proper attention for the social origin and character of values and for social mechanisms such as enforcement.

In this article, a more comprehensive theory of values in water management will be developed, using both socialpsychological and political science literature, in order to inform future socio-hydrological research. The article covers both 
Hydrol. Earth Syst. Sci. Discuss., https://doi.org/10.5194/hess-2018-498

Manuscript under review for journal Hydrol. Earth Syst. Sci.

Discussion started: 2 October 2018

fundamental values and applied behavioural norms. The first section discusses the different types of values and how they can influence behaviour, while the second section discusses their origin and evolution. The third section discusses methods for measuring different types of values. The discussion section gives recommendations for future socio-hydrological research. The article closes with a short conclusion.

\section{2. Values: what they are and how they work}

As mentioned in the introduction, values can be described as principles or standards of behaviour. They can be used to judge and justify behaviour, and they can be enacted in practice and embodied in physical artefacts, such as reservoirs, and institutions, such as water laws. Following Schwartz (1992), these two functional types will be called ideal values and actual values. Ideal values are often mentioned in public discussions and in policy documents, mission statement and similar documents. Actual values, by contrast, are what really motivates actual behaviour and can best explain this.

Both ideal and actual values may be either individual or social. Individual values are the principles and standards of behaviour that an individual uses or enacts, and social values are the values that a group, organisation or country uses or enacts. Social values may differ a lot from individual values. In public discussions not everybody may be free to express their values, there may be pressure to conform or conversely the discussions may get polarised (cf. Wutich et al., 2010).

15 Policy documents and similar documents reflect primarily the values of those who draft and adopt them. The same is true for social values that are enacted in practice: they too reflect primarily the values of the most powerful actors.

When social and individual values are similar, this is not necessarily because the social values reflect individual values: the reverse may also be true. First, individuals are socialised and develop most of their values early in life (see the next section). Secondly, when induced to act according to social values that conflict their personal values, individuals may modify their

20 personal values in order to reduce cognitive dissonance (cf. Mills, 1958; Felson, 2014). Thirdly, selection and self-selection may be at work: groups and organisations may attract or select individuals that adhere to their values and are more likely to retain these individuals than individuals with conflicting values.

The relation between facts and values is controversial. While many authors separate facts and values, arguing for instance that "ought” cannot be derived from "is", other authors try to ground values in the necessities of human existence (Schwartz,

25 1994) or the need to live together and form functioning societies (Hofstede, 1991). In this context several fundamental tensions are mentioned, such as the individual versus the collectively, equality versus hierarchy, and tradition and security versus development and change (Thompson et al., 1990; Hofstede, 1991; Schwartz, 1994; Schwartz, 2006). Specific values can be located at the opposite ends of these different dimensions. This results in typologies of values such as the one presented in Table 1. 
Hydrol. Earth Syst. Sci. Discuss., https://doi.org/10.5194/hess-2018-498

Manuscript under review for journal Hydrol. Earth Syst. Sci.

Discussion started: 2 October 2018

Table 1: An example of a typology of values (Schwartz, 2006), based on three dimensions: embeddedness versus intellectual and affective autonomy, hierarchy versus egalitarianism, and mastery versus harmony. Values are compatible with values of an adjacent type (e.g. embeddedness and harmony) but conflict with values of the opposite type (e.g. embeddedness and autonomy).

\begin{tabular}{ll}
\hline Types of values & Examples \\
\hline 1. Harmony & Unity with nature, environmental protection, beauty, peace \\
2. Embeddedness & Order, obedience, tradition, security, politeness \\
3. Hierarchy & Authority, humbleness, wealth, power \\
4. Mastery & Ambition, daring, influence, success, recognition, setting own goals \\
5. Affective autonomy & Pleasure, excitement, variety \\
6. Intellectual autonomy & Broadmindedness, curiosity, creativity, freedom \\
7. Egalitarianism & Justice, equality, honesty, loyalty, responsibility, accept portion in life \\
\hline
\end{tabular}

5 Values can influence behaviour in different ways. In VBN theory behaviour is motivated by fundamental personal values, but mediated by personal beliefs that these values are under threat and that the individual can help to alleviate this threat. In addition, behaviour is influenced by personal capabilities, such as knowledge, skills and finances, and by contextual factors, such as community expectations, advertising, government regulation, and financial incentives (Stern, 2002).

As briefly mentioned by Stern et al. (1999) and Stern (2002), values can also have a direct effect on behaviour, independent

10 of personal beliefs. This will happen when observance of the value gives positive feelings and non-observance negative feelings, for instance feelings of guilt. ${ }^{1}$ Crawford and Ostrom (1995) have proposed to model this effect by adding a "delta parameter” to the benefits of observance or the costs of non-observance (see also Ostrom, 2010).

Social values and especially social norms can also influence behaviour via enforcement. Formal norms, such as legal rules on water abstractions, can be enforced by the police or guards, who may impose fines or institute legal proceedings. Informal

15 norms are often enforced by the parties interested in the norm (Ostrom, 1990). Sanctions can include reputational damage and social exclusion (e.g. Yu et al., 2017; see also the discussion in the next section on reciprocity). The effectiveness of enforcement has been found to depend on the (perceived) probability, severity and swiftness of the sanction and on individual characteristics, such as the degree self-control. In addition, the social context is important (Worrall et al., 2014). In small communities, for instance, transgression of norms is detected more easily and informal sanctions can be applied more

20 easily and have more serious consequences than in large anonymous societies.

Social values can also influence behaviour indirectly via the physical artefacts and social institutions (e.g. cultural practices) which they have helped to create. Artefacts and institutions may change and may come to serve different purposes (Cleaver, 2002). Nonetheless, they can have significant staying power and exert an influence long after the values on which they were

\footnotetext{
${ }^{1}$ Cf. the distinction in ethics between consequentialist ethics, according to which actions are right or wrong depending on their consequences, and deontological ethics, according to which actions are right or wrong in themselves, depending on whether they comply or conflict with duties, obligations, rules or values.
} 
Hydrol. Earth Syst. Sci. Discuss., https://doi.org/10.5194/hess-2018-498

Manuscript under review for journal Hydrol. Earth Syst. Sci.

Discussion started: 2 October 2018

Hydrology and

Earth System

(c) Author(s) 2018. CC BY 4.0 License.

Sciences

Discussions

(c) (i)

once based have changed. For example, the Dutch polder system was developed in the Middle Ages primarily to increase agricultural production (Van de Ven, 2004), but it still dominates the Dutch landscape now that recreational and environmental values have become important as well.

When in a specific case different values conflict, the question is which one will prevail. In the case of collective action, such

5 as the construction of a large reservoir, this question is answered politically. Farmers, environmental NGOs, downstream countries and other stakeholders will lobby or negotiate with those in power, who will have their own views and interests as well.

In the case of individual action, the question is answered individually. In the rational choice model of human behaviour (Vatn, 2009; Elsenbroich and Gilbert, 2014), the individuals concerned will choose the option that maximizes their

10 individual "utility". For example, if a farmer can comply with a social norm to contribute to the upkeep of the local flood defences or freeride on the efforts of others and save time and money, they will do the latter or, if they have internalised the social norm or if it is actively enforced, balance the benefits of freeriding against the costs of non-compliance.

The main problem with the rational choice model is the assumption of rationality. There is ample evidence that most of the time people do not consciously balance costs and benefits, but act instantaneously on the basis of intuition and association,

15 following simplifying rules or "heuristics" (Kahneman, 2011). According to Vatn (2009), different institutional settings may activate different values. In market-like settings, people tend to act economically rational and maximise their net private gains, whereas family and community settings activate pro-social values. This may explain why environmental taxes and subsidies do not always promote pro-environmental behaviour. For individuals that already focused on individual costs and benefits, environmental taxes and subsidies may tip the balance in favour of the more environmentally friendly option. For

20 other individuals, the effect of may be to draw attention to individual costs and benefits at the expense of pro-environmental considerations. The overall effect can be less instead of more environmentally friendly behaviour (Steg, 2016).

\section{The origin and development of values}

Values may have different origins. A first explanation is direct reciprocity (Axelrod, 1984; Nowak, 2006). Actors that interact repeatedly may act cooperatively in order to increase the chance that the others will reciprocate or, as the case may

25 be, continue to reciprocate this behaviour. Direct reciprocity may not explain the development of fundamental values, but it can explain the development of norms of cooperation, provided there is repeated interaction.

In the absence of repeated interaction, norms of cooperation may be explained by indirect (Nowak, 2006) or generalised (Putnam et al., 1994) reciprocity. Generalised reciprocity works via reputation. Actors who are seen to cooperate improve their reputation and are more likely to receive help themselves. Generalised reciprocity is most effective in communities with 30 many horizontal social connections ("social capital”: Putnam, 2001). Social connections entail mutual obligations, as when individual A does individual $\mathrm{B}$ a favour in the expectation that $\mathrm{B}$ will return the favour in the future. When social connections are widespread, A may do B a favour without expecting anything in return from B, but expecting future favours 
Hydrol. Earth Syst. Sci. Discuss., https://doi.org/10.5194/hess-2018-498

Manuscript under review for journal Hydrol. Earth Syst. Sci.

Discussion started: 2 October 2018

Hydrology and

Earth System

(c) Author(s) 2018. CC BY 4.0 License.

Sciences

Discussions

(c) (i)

by other community members. Widespread social networks reduce possibilities for opportunism as this threatens the reputation of the person involved, they increase social trust, and they foster norms of cooperation (Putnam, 2001). The development of norms of cooperation seems indispensable: without such norms opportunism would not be viewed negatively and would not result in reputational damage.

5 Cooperation can be stimulated by community values such as solidarity. Solidarity refers to both mutual support in furthering a common interest and support for needy community members (Keessen et al., 2016). While there is often an element of reciprocity, the main motivation of solidarity is not self-interest, but a sense of being similar and recognising oneself in others, sympathising with others, having a common identity and constituting a "we” and not only separate "I’s” (Tönnies and Loomes, 1963; Selznick, 1994). For sustaining a sense of community, it is important that people feel that they matter to the

10 community and the community to them, and that their (emotional) needs are met (cf. McMillan and Chavis, 1986).

Civic values are comparable to solidarity, but more abstract. They refer to the importance of contributing to the community, for instance by voting or volunteering, even if there are no direct personal benefits. Civic values as well as other values can be internalised early in life ('socialisation'). This may involve a combination of conditioning; explanation, learning by example, and discovery, e.g. learning with peers the benefits of reciprocity (e.g. Selznick, 1994, chapter 6; Elsenbroich and

15 Gilbert, 2014, section 2.2). National differences in child rearing and education may explain much of the national differences in values.

Specific norms can also be designed explicitly. This is certainly true for legal norms that are officially enacted. Enacting norms usually involves lengthy discussions and much negotiation, the outcome of which cannot be predicted with certainty. In addition, the norms may function differently as intended. Nonetheless, they can play an important role in practice.

20 As norms can be designed, they can also be redesigned. In addition, values can change as a result of new information. Most values have a factual element in them and can be justified in terms of their instrumental value for realising more fundamental values, such as human wellbeing and freedom. According to VBN theory, new information can lead to changes in beliefs, which in turn can change behavioural norms. This is, however, not a straightforward process. For example, people may agree that the past few years have been exceptionally dry and hot, but they may not agree whether this is an effect of climate change or just climate variability and, if climate change, what can be done about it. Since "climate" refers to statistical averages and cannot be observed directly, most people have to rely on scientific research and especially media reports. Whether they believe these reports and pay attention to them at all depend on their worldviews, their fundamental values and political ideology, and the trust they have in the scientists and the media (Weber, 2010, 2016; cf. Wynne, 1992).

Values can also change as a result of socio-economic change. Socio-economic change may result not only in the growth of

30 specific groups with specific interests and values (Roobavannan et al., 2017), but also in a change of these values as a result of for instance increased wealth, higher education levels, and more leisure time (Mostert, 2018b). According to Human Development theory (Welzel et al., 2003), economic growth increases the resources and possibilities of individuals. This would result in a shift from traditional survival values to self-expression values, and in pressure for more political freedom and democracy. The developments in many Western countries in the 1960s offer support for this theory. Following years of 
Hydrol. Earth Syst. Sci. Discuss., https://doi.org/10.5194/hess-2018-498

Manuscript under review for journal Hydrol. Earth Syst. Sci.

Discussion started: 2 October 2018

(c) Author(s) 2018. CC BY 4.0 License.

(c) (i)
Hydrology and

Earth System

Sciences

Discussions

economic growth and increases in levels of education, traditional bonds relaxed, churchgoing diminished, and the authority of the old elites was questioned, and especially young people demanded more rights and more influence. This led, among others, to large-scale student revolts in 1968 in Paris, Berlin and Berkeley (e.g. Righart, 1998).

It would be possible to look among the different possible explanations of values for a root cause, such as environmental conditions, economic interests, power, or "culture". These "root causes" are, however, not independent of each other, and the factors that can best explain values may differ from case to case.

\section{Measuring values}

Without actually measuring values, quantitatively or qualitatively, it is impossible to test any assertion concerning the role of values in water management. The methods that can be used for measuring depend on the type of value (Table 2).

10

Table 2: Methods for measuring different types of values

\begin{tabular}{|c|c|c|}
\hline & Individual & Social \\
\hline Ideal & $\begin{array}{ll}\text { - } & \text { Surveys } \\
\text { - } & \text { Interviewing } \\
\text { - } & \text { Q methodology }\end{array}$ & $\begin{array}{ll}\text { - } & \text { Surveys }^{\mathrm{a}} \\
\text { - } & \text { Interviewing }^{\mathrm{a}} \\
\text { - } & \text { Q methodolog } \\
\text { - } & \text { Discourse analysis of cultural texts (newspapers, } \\
& \text { social media, etc.) } \\
\text { - } & \text { Focus groups }\end{array}$ \\
\hline Actual & $\begin{array}{l}\text { - Inference from observed or reported actions } \\
\text { and individual artefacts }\end{array}$ & $\begin{array}{l}\text { - Inference from collective action and cultural } \\
\text { artefacts }\end{array}$ \\
\hline
\end{tabular}

a: Only if social values closely reflect individual values

Surveys are a good method for measuring individual ideal values. Questions can be included that ask directly about specific

15 values, such as "how important in your life is it to experience unity with nature" or "become rich. (1: not important at all; 5 : extremely important)". Survey research does have some pitfalls, however (Kelley et al., 2003). Respondents may give socially desirable answers. They may interpret questions differently than intended, the exact wording of the questions can have a large impact on the responses, and in international surveys there are translation problems. Moreover, people may be asked for opinions they do not have, which they may then invent at the spot. Response may be low and not representative of

20 the group or groups targeted. Setting up and administering a survey requires specific expertise and a lot of time, and unless one is willing and able to repeat the survey, it is impossible to study changes in time. 
Hydrol. Earth Syst. Sci. Discuss., https://doi.org/10.5194/hess-2018-498

Manuscript under review for journal Hydrol. Earth Syst. Sci.

Discussion started: 2 October 2018

An alternative for original survey research is to use data from existing surveys, such as the World Values Survey (www.worldvaluessurvey.org) or the European Social Survey (www.europeansocialsurvey.org) (e.g. Bjørnskov, 2006). The first data for the World Values Survey were collected already in 1981-1982, but only ten countries were covered. (The last completed "wave" in 2010-2014 covered sixty countries.) Moreover, the data are national. Data from the European Social

5 Survey are available at a disaggregated level as well, but for most countries the units used are Eurostat's statistical regions (the "NUTS" regions) rather than river basins or other hydrologically relevant units, and the sample size per region is rather small.

A third option is to set up a new survey but using a tested questionnaire or questions from a tested questionnaire, such as the Schwartz Value Survey or the Portrait Values Questionnaire (Schwartz, 2006, 2009; Sandy et al., 2017). This requires less,

10 but still significant, time and expertise than completely original case study research.

In addition to surveys, interviews and Q methodology can be used to measure individual ideal values. Interviews can include questions on for instance the important water issues for the interviewee, what he or she thinks can and should be done about them and, crucially, why. Of each interview an interview report should be made, which can then be analysed using a procedure called coding (Merriam and Tisdell, 2016). This involves, first, the development of a set of codes: relevant themes

15 or topics, e.g. values that are mentioned or referred to. The codes can be based on a relevant theory (e.g. Bark et al., 2016), they can be identified inductively, during the research, and they can be mixed, for instance based mostly on existing theories or approaches but complemented with codes that emerged during the research (e.g. Mostert, 2015b; Haeffner et al., 2018). The second step is to assign the codes to relevant segments of the interviews reports. Following, overviews can be made of all relevant segments on a specific theme or topic and patterns may emerge, e.g. correspondence between types of

20 interviewee and themes mentioned. These patterns can then be further analysed. Different qualitative data analysis software packages are available to support coding (Duff and Séror, 2005).

Q methodology involves several steps (Van Exel and De Graaf, 2005):

1. Collection of possible statements about the issue at hand (the "concourse”), using documents and interviews

2. Selection of the 25 or 40 most relevant statements (the "Q set")

$253 . \quad$ Selection of respondents (the "P set")

4. Ranking of statements by the respondents according to how much they agree with each, e.g. from 1 (agree least) to 5 (agree most), using a fixed distribution over the different categories ("Q $\mathrm{Q}$ sorting”).

5. Statistical analysis of the resulting Q sort, resulting in a limited number of factors that can explain most the observed diversity

306 . Interpretation of the factors, focusing on the statements that have very different average scores

$\mathrm{Q}$ methodology can be used with a limited number of respondents and results in an overview of different subjective views (the interpreted factors). It is not possible to quantify the frequency of the different views. Examples of the use of Q methodology concerning water issues include Raadgever et al. (2008), Vugteveen et al. (2010) and Forrester et al. (2015). 
Hydrol. Earth Syst. Sci. Discuss., https://doi.org/10.5194/hess-2018-498

Manuscript under review for journal Hydrol. Earth Syst. Sci.

Discussion started: 2 October 2018

Hydrology and

Earth System

(c) Author(s) 2018. CC BY 4.0 License.

Sciences

Discussions

(c) (i)

For measuring social ideal values the same methods may be used as for measuring individual ideal values, but only if the social values reflect the individual values quite closely. In other cases social values have to be measured more directly, using for instance discourse analysis of cultural “texts”. Discourse analysis consists of three steps (Fairclough, 2003). The first step is the identification and, if there are too many, selection of relevant texts. Relevant texts may include newspaper reports (Wei

5 et al., 2017), children’s books (Mostert, 2015b), official minutes of parliamentary discussions (Mostert, 2018a) and online comments (Bark et al., 2016), as well as pictures and other artefacts with a symbolic meaning. The next steps are the identification of key themes in the texts and an analysis of how these themes are covered. For this coding as described above may be used. Since the texts that may be analysed can go back a long time, discourse analysis is often a good method for studying long-term developments.

10 A second method for measuring social ideal values directly is focus group research. A focus group is a small group that discusses a topic determined by the researcher. The discussions are usually moderated. They can get polarised, participants may be effectively censored, and there may be pressure for conformity (Wutich et al., 2010). Hence, focus group research does not necessarily yield reliable data on individual ideal values, but it does yield data on the social ideal values of that group. To the extent that the focus group is a microcosm of larger groups, organisations or whole societies, the results may

15 be used as an indicator of the social ideal values of that group, organisation or society.

Actual social values cannot be measured directly, but they can be inferred from collective action and cultural artefacts, such as water management infrastructure. There is, however, a serious risk of circular reasoning, for example when one uses the construction of a sewage treatment plant as an indicator of actual environmental values and then uses these values to explain the construction of the sewage treatment plant. That is only allowable if there are several independent indicators of these

20 values. The major advantage of inference is that no significant bodies of text are needed. It can therefore can also be used in the study of pre-historic civilizations (e.g. Pande and Ertsen, 2014).

Just like actual social values, actual individual values can only be inferred, in this case from individual behaviour and individual artefacts. Individual behaviour can be observed directly, e.g. during field visits, or it can be derived from for instance election results (election behaviour) and membership figures of social organisations. In addition, behaviour may be

25 self-reported, e.g. in interviews or in responses to surveys that ask about activities. Putnam's book Bowling alone: The collapse and revival of American community is a well-known example of the use of membership figures and survey data to infer values, viz. a decline in community and civic values in the USA (Putnam, 2001).

For more guidance on the methods discussed in this section, the reader is referred to the literature cited and to the general literature on research methodology.

\section{5. Discussion}

This paper has discussed the nature and origin of values and how they can be measured. Values are principles or standards of behaviour that can be used to judge and justify behaviour (ideal values) and can be enacted in practice and embodied in 
Hydrol. Earth Syst. Sci. Discuss., https://doi.org/10.5194/hess-2018-498

Manuscript under review for journal Hydrol. Earth Syst. Sci.

Discussion started: 2 October 2018

Hydrology and

Earth System

(c) Author(s) 2018. CC BY 4.0 License.

Sciences

Discussions

(c) (i)

physical artefacts and institutions (actual values). They can help explain how humans interact with their environment. Analysis in terms of values does not assume that actors rationally choose the best means for reaching given ends, but it does not assume that actors are irrational either. Values are not arbitrary. They are the answers that societies have developed to cope with the challenges of human existence, such as balancing individual autonomy and group interests (Selznick, 1994).

5 These answers may be more or less effective in terms of human wellbeing and personal freedom, and they may change as new information becomes available or as a result of socio-economic change.

Analysis in terms of values does not replace hydrological, economic or political analysis. To be effective, the answers that values provide should respect hydrological constraints and meet basic economic needs, such as food and shelter, as well as emotional needs. Moreover, values may serve some groups more than others. When they are stable, values can be ignored

10 and hydrological change and societal response can be linked directly, using for instance rational choice approaches that treat ends as given. As soon as values change, however, the ends change and the relation between hydrological change and societal response may change as well.

Depending on the type of values - ideal or actual, individual or social -, different measurement methods can be used, such as surveys, interviews, Q methodology, discourse analysis, focus group research, and inference. The choice of method will depend on practical considerations, such as the available data sources, time and expertise, but also on the question which type of values is most relevant.

For socio-hydrological research actual values seem more relevant than ideal values because they are directly linked with societal response. Nonetheless, there are good reasons for studying ideal values too. They are not inconsequential. Even those in power need to legitimise - and be able to legitimise - their actions in terms of ideal values to secure support and

20 reduce the costs of exercising their power (cf. Majone, 1989). Ideal values play an important role in ethical and political discussions that influence societal response. Besides, good data sources may be available, such as the World Values Survey or the European Social Survey.

The issue of studying individual or social values is comparable to the issue how to model socio-hydrological systems: by means of lumped models that treat society as one actor or agent-based models that start from the individual level. The disadvantage of lumped models is that they provide no insight in the internal dynamics of society, such as the interactions between upstream and downstream actors or farmers and city dwellers (Mostert, 2018b). The disadvantage of starting from the individual level is the difficulty, if not impossibility, of modelling the development of complex social structures such as water laws and water treaties, river basin commissions and regional organisations such as the European Union with its water directives. These structures could be included in the models as fixed constraints, but in the long term they are not fixed.

30 In this article I propose a third alternative: to start analysis at the intermediate level of social groups and organisations. Social groups may not only change in size (Roobavannan et al., 2017), but also in character, e.g. as a result of broader socioeconomic change (Mostert, 2018b). They may even disappear completely and new ones may emerge. Similarly, water management organisations may get new tasks. They may be amalgamated or abolished, and new ones may be established. The different groups and organisations interact with each other. In the short term their interactions are influenced by 
Hydrol. Earth Syst. Sci. Discuss., https://doi.org/10.5194/hess-2018-498

Manuscript under review for journal Hydrol. Earth Syst. Sci.

Discussion started: 2 October 2018

different social values and management institutions (e.g. laws), but in the longer term they also change these values and institutions, or at least contribute to their change. Similarly, the different groups and organisations not only depend on their physical environment, but also influence or actively modify the environment. Complicating matters, the groups and organisations influencing the environment may differ from those experiencing the consequences, as when upstream activities

5 lead to problems downstream. Moreover, there may be a time lag between change and consequences. How these complications are handled depends on the prevalent social values and management institutions.

The alternative proposed is very flexible. Starting from a specific topic and aim, e.g. to understand the development of a highly engineered river system, the most relevant groups and organisations and the most relevant geographical and time scales can be identified during the research. Moreover, it is possible to temporarily shift attention to smaller or larger scales

10 if this proved to be necessary for understanding the internal dynamics of groups and organisations and the role of key individuals, or the broader context of specific groups and organisations. The most suitable research approach is detailed qualitative case study research. As I argued elsewhere, this can be combined with hydrological modelling of the impact of human actions and with coupled toy models (Mostert, 2018b).

\section{Conclusion}

15 This paper has discussed the role of values in water management and the different measurement methods that can be used. For research into the co-evolution of human and water systems, the most promising measurement method is discourse analysis of cultural texts such as newspapers or the minutes of management bodies because such texts are often available for longer periods. In the absence of such texts, the only option is inference from observations, e.g. archaeological remains. For comparative studies, data from the World Values Survey or the European Social Survey may be used, provided the countries

20 of interest have been included in these surveys and bearing in mind that the data refer primarily to individual values. Future socio-hydrological research should take as its starting point the main social groups and organisations in the area of interest and study 1) how these have evolved, 2) how their interactions with each other and with their physical environment have evolved, and 3) how they influence and are influenced by the prevalent social values and management institutions.

Data availability. No data sets were used in this article.

Competing interests. The author declares that he has no conflict of interests.

\section{References}

Axelrod, R. M.: The evolution of cooperation, Basic Books, New York, 1984. 
Hydrol. Earth Syst. Sci. Discuss., https://doi.org/10.5194/hess-2018-498

Manuscript under review for journal Hydrol. Earth Syst. Sci.

Discussion started: 2 October 2018

Hydrology and

Earth System

(c) Author(s) 2018. CC BY 4.0 License.

Sciences

Discussions

(c) $\underset{\mathrm{BY}}{\mathrm{BY}}$

Bark, R. H., Robinson, C. J., and Flessa, K. W.: Tracking cultural ecosystem services: water chasing the Colorado River restoration pulse flow, Ecol.l Econ., 127, 165-172, https://doi.org/10.1016/j.ecolecon.2016.03.009, 2016.

Bjørnskov, C.: The multiple facets of social capital, Eur. J. Polit. Econ., 22, 22-40, https://doi.org/10.1016/j.ejpoleco.2005.05.006, 2006.

5 Cleaver, F.: Reinventing institutions: Bricolage and the social embeddedness of natural resource management, Eur. J. Dev. Res., 14, 11-30, https://doi.org/10.1080/714000425, 2002.

Crawford, S. E., and Ostrom, E.: A grammar of institutions, Am. Polit. Sci. Rev., 89, 582-600, https://doi.org/10.2307/2082975, 1995.

Duff, P. A., and Séror, J.: Computers and qualitative data analysis: Paper, pens, and highlighters vs. screen, mouse, and

10 keyboard, Tesol Quart., 39, 321-328, https://doi.org/10.2307/3588315, 2005.

Elsenbroich, C., and Gilbert, N.: Modelling norms, Springer, Dordrecht Heidelberg New York London, 2014.

Fairclough, N.: Analysing discourse: Textual analysis for social research, Routledge, Abingdon/ New York, 2003.

Felson, M.: Book reviews. Breaking rules: the social and situational dynamics of young people's urban crime, Journal of Criminal Justice Education, 25, 254-258, https://doi.org/10.1080/10511253.2014.895497, 2014.

15 Haeffner, M., Jackson-Smith, D., and Flint, C. G.: Social Position Influencing the Water Perception Gap Between Local Leaders and Constituents in a Socio-Hydrological System, Water Resources Research, 54, 663-679, https://doi.org/10.1002/2017WR021456, 2018.

Forrester, J., Cook, B., Bracken, L., Cinderby, S., and Donaldson, A.: Combining participatory mapping with Qmethodology to map stakeholder perceptions of complex environmental problems, Appl. Geogr., 56, 199-208,

20 https://doi.org/10.1016/j.apgeog.2014.11.019, 2015.

Hofstede, G. H.: Cultures and organizations : software of the mind, McGraw-Hill, London New York, 1991.

Kahneman, D.: Thinking, fast and slow, Penguin, London, 2011.

Keessen, A., Vink, M. J., Wiering, M., Boezeman, D., Ernst, W., Mees, H., Van Broekhoven, S., and Van Eerd, M. C.: Solidarity in water management, Ecol. Soc., 21, https://doi.org/10.5751/ES-08874-210435, 2016.

25 Kelley, K., Clark, B., Brown, V., and Sitzia, J.: Good practice in the conduct and reporting of survey research, Int. J. Qual. Health C., 15, 261-266, https://doi.org/10.1093/intqhc/mzg031, 2003.

Majone, G.: Evidence, argument, and persuasion in the policy process, Yale University Press, New Haven, 1989.

McMillan, D. W., and Chavis, D. M.: Sense of community: A definition and theory, J. Community Psychol., 14, 6-23, https://doi.org/10.1002/1520-6629(198601)14:1<6::AID-JCOP2290140103>3.0.CO;2-I, 1986.

30 Merriam, S. B., and Tisdell, E. J.: Qualitative research: A guide to design and implementation, 4 ed., Jossey-Bass, San Francisco, 2016.

Mills, J.: Changes in moral attitudes following temptation, J. Pers., 26, 517-531, https://doi.org/10.1111/j.14676494.1958.tb02349.x, 1958. 
Hydrol. Earth Syst. Sci. Discuss., https://doi.org/10.5194/hess-2018-498

Manuscript under review for journal Hydrol. Earth Syst. Sci.

Discussion started: 2 October 2018

Hydrology and

Earth System

(c) Author(s) 2018. CC BY 4.0 License.

Sciences

Discussions

(c) $\underset{\mathrm{By}}{\mathrm{i}}$

Mostert, E.: Who should do what in environmental management?; Twelve principles for allocating responsibilities, Environm. Sci. Policy, 45, 123-131, http://dx.doi.org/10.1016/j.envsci.2014.10.008, 2015a.

Mostert, E.: Children’s books as a historical source; flooding in 20th century Dutch children’s books, Water History, 7, 357370, 10.1007/s12685-014-0116-4, 2015b.

5 Mostert, E.: River basin management and community; The Great Ouse Basin, 1850-present, International Journal of River Basin Management, 16, 51-59, 10.1080/15715124.2017.1339355, 2018a.

Mostert, E.: An alternative approach for socio-hydrology: case study research, Hydrol. Earth Syst. Sc., 22, 317-329, https://doi.org/10.5194/hess-22-317-2018, 2018 b.

Nowak, M. A.: Five rules for the evolution of cooperation, Science, 314, 1560-1563,

10 https:\doi.or\10.1126/science.1133755, 2006.

Ostrom, E.: Governing the commons: the evolution of institutions for collective action, The Political economy of institutions and decisions, Cambridge University Press, Cambridge, 1990.

Ostrom, E.: Analyzing collective action, Agr. Econ., 41, 155-166, https://doi.org/10.1111/j.1574-0862.2010.00497.x, 2010.

Pande, S., and Ertsen, M.: Endogenous change: on cooperation and water availability in two ancient societies, Hydrol. Earth

15 Syst.Sc., 18 (5), 2014, https://doi.org/10.5194/hess-18-1745-2014, 2014.

Putnam, R. D., Leonardi, R., and Nanetti, R. Y.: Making democracy work: Civic traditions in modern Italy, Princeton University Press, 1994.

Putnam, R. D.: Bowling alone: The collapse and revival of American community, Simon and Schuster, New York, 2001.

Raadgever, G. T., Mostert, E., and van de Giesen, N. C.: Measuring perspectives on future flood management on the Rhine:

20 application and discussion of Q methodology, Hydrol. Earth Syst. Sc., 12, 1097-1109, https://doi.org/10.5194/hess-12-10972008, 2008.

Righart, H.: Moderate versions of the 'global sixties': A comparison of Great Britain and the Netherlands, Journal of Area Studies, 6, 82-96, 1998.

Roobavannan, M., Kandasamy, J., Pande, S., Vigneswaran, S., and Sivapalan, M.: Role of sectoral transformation in

25 evolution of water management norms in agricultural catchments: a socio-hydrologic modeling analysis, Water Resour. Res., 8344-8365, https://doi.org/10.1002/2017WR020671, 2017.

Roobavannan, M., van Emmerik, T. H., Elshafei, Y., Kandasamy, J., Sanderson, M. R., Vigneswaran, S., Pande, S., and Sivapalan, M.: Norms and values in sociohydrological models, Hydrol. Earth Syst. Sc., 22, 1337, 2018, https://doi.org/10.5194/hess-22-1337-2018, 2018.

30 Sanderson, M. R., and Curtis, A. L.: Culture, climate change and farm-level groundwater management: An Australian case study, J. Hydrol., 536, 284-292, 10.1016/j.jhydrol.2016.02.032, 2016.

Sanderson, M. R., Bergtold, J. S., Heier Stamm, J. L., Caldas, M. M., and Ramsey, S. M.: Bringing the “social” into sociohydrology: Conservation policy support in the Central Great Plains of K ansas, USA, Water Resources Research, 53, 6725-6743, https://doi.org/10.1002/2017WR020659, 2017. 
Hydrol. Earth Syst. Sci. Discuss., https://doi.org/10.5194/hess-2018-498

Manuscript under review for journal Hydrol. Earth Syst. Sci.

Discussion started: 2 October 2018

Hydrology and

Earth System

Sciences

(c) Author(s) 2018. CC BY 4.0 License.

Discussions

(c) (i)

Sandy, C. J., Gosling, S. D., Schwartz, S. H., and Koelkebeck, T.: The development and validation of brief and ultrabrief measures of values, Journal of personality assessment, 99, 545-555,https://doi.org/10.1080/00223891.2016.1231115, 2017.

Schwartz, S. H.: Universals in the content and structure of values: Theoretical advances and empirical tests in 20 countries, in: Adv. Exp. Soc. Psychol., 1-65, https://doi.org/10.1016/S0065-2601(08)60281-6, 1992.

5 Schwartz, S. H.: Are there universal aspects in the structure and contents of human values?, J. Soc. Issues, 50, 19-45, https://doi.org/10.1111/j.1540-4560.1994.tb01196.x , 1994.

Schwartz, S. H.: A theory of cultural value orientations: Explication and applications, Comp. Sociol., 5, 137-182, https://doi.org/10.1163/156913306778667357, 2006.

Schwartz, S. H.: Draft Users Manual: Proper Use of the Schwarz Value Survey, version 14 January 2009, compiled by

10 Romie F. Littrell. Auckland, New Zealand: Centre for Cross Cultural Comparisons, Manuscript. Available at: http://crossculturalcentre. homestead. co m/(Accessed July, 16, 2013, 2009.

Selznick, P.: The moral commonwealth: Social theory and the promise of community, Univ of California Press, Berkeley and Los Angeles, 1994.

Steg, L.: Values, norms, and intrinsic motivation to act proenvironmentally, Annu. Rev. Env. Resour., 41, 277-292,

15 https://doi.org/10.1146/annurev-environ-110615-085947, 2016.

Stern, P. C., Dietz, T., Abel, T., Guagnano, G. A., and Kalof, L.: A value-belief-norm theory of support for social movements: The case of environmentalism, Hum. Ecol. Rev., 81-97, https://www.jstor.org/stable/24707060, 1999.

Stern, P. C.: New environmental theories: toward a coherent theory of environmentally significant behavior, J. Soc. Issues, 56, 407-424, https://doi.org/10.1111/0022-4537.00175, 2002.

20 Stevenson, A.: Oxford dictionary of English, Oxford University Press, Oxford, 2010.

Thompson, M., Ellis, R., and Wildavsky, A. B.: Cultural theory, Political cultures, Westview Press, Boulder, Colo., 1990.

Tönnies, F., and Loomes, C. P. (ed. and transl.): Community and society, Harper Torchbooks, New York, 1963.

Van de Ven, G. P.: Man-made lowlands history of water management and land reclamation in the Netherlands. Matrijs, Utrecht, 2004.

25 Van Exel, J., and De Graaf, G.: Q methodology: A sneak preview, available at Researchgate.net, 2005.

Vatn, A.: Cooperative behavior and institutions, J. Socio-Econ., 38, 188-196, http://dx.doi.org/10.1016/j.socec.2008.07.011, 2009.

Vugteveen, P., Lenders, H. R., Devilee, J. L., Leuven, R. S., Van der Veeren, R. J., Wiering, M. A., and Hendriks, A. J.: Stakeholder value orientations in water management, Society and natural resources, 23, 805-821, 30 https://doi.org/10.1080/08941920903496952, 2010.

Weber, E. U.: What shapes perceptions of climate change?, Wires Clim. Change, 1, 332-342, https://doi.org/10.1002/wcc.41, 2010.

Weber, E. U.: What shapes perceptions of climate change? New research since 2010, Wires Clim. Change, 7, 125-134, https://doi.org/10.1002/wcc.377, 2016. 
Hydrol. Earth Syst. Sci. Discuss., https://doi.org/10.5194/hess-2018-498

Manuscript under review for journal Hydrol. Earth Syst. Sci.

Discussion started: 2 October 2018

(C) Author(s) 2018. CC BY 4.0 License.

(c) (i)
Hydrology and Earth System

Sciences

Discussions

Wei, J., Wei, Y., and Western, A.: Evolution of the societal value of water resources for economic development versus environmental sustainability in Australia from 1843 to 2011, Global Environ. Chang., 42, 82-92, https://doi.org/10.1016/j.gloenvcha.2016.12.005, 2017.

Welzel, C., Inglehart, R., and Klingemann, H.-D.: The theory of human development: a cross-cultural perspective, Eur. J.

5 Polit. Res., 42, 341-379, https://doi.org/10.1111/1475-6765.00086, 2003.

Worrall, J. L., Els, N., Piquero, A. R., and TenEyck, M.: The moderating effects of informal social control in the sanctionscompliance nexus, Am. J. Crim. Just., 39, 341-357, https://doi.org/10.1007/s12103-013-9211-9, 2014.

Wutich, A., Lant, T., White, D. D., Larson, K. L., and Gartin, M.: Comparing focus group and individual responses on sensitive topics: a study of water decision makers in a desert city, Field Method., 22, 88-110, https://doi.org/10.1177/1525822X09349918, 2010.

Wynne, B.: Misunderstood misunderstanding: Social identities and public uptake of science, Public Understanding of Science, 1, 281-304, https://doi.org/10.1088/0963-6625/1/3/004, 1992.

Yu, D. J., Sangwan, N., Sung, K., Chen, X., and Merwade, V.: Incorporating institutions and collective action into a sociohydrological model of flood resilience, Water Resour. Res., 53, 2, 1336-1353, https://doi.org/10.1002/2016WR019746, 152017. 